\title{
HEALTH ASPECTS OF EXPOSURE TO EMISSIONS FROM BURNING COAL OF HIGH BERYLLIUM CONTENT: INTERACTIONS WITH THE IMMUNE SYSTEM
}

\author{
Jitka Petanová1, Vladimír Bencko² \\ ${ }^{1}$ Institute of Immunology and Microbiology, First Faculty of Medicine, Charles University and General University Hospital in Prague, Prague, \\ Czech Republic \\ ${ }^{2}$ Institute of Hygiene and Epidemiology, First Faculty of Medicine, Charles University, Prague, Czech Republic
}

\section{SUMMARY}

Beryllium has an impact on the human health of professionally or non-occupationally exposed people. Current evidence suggests that beryllium acts as a hapten with limited antigenic properties and is presented by antigen presenting cells to $\mathrm{CDL}^{+} \mathrm{T}$ cells, which possess specific antigen receptors. The immunological changes in humoral immunoreactivity were considered biomarkers of beryllium exposure. In the present, due to the development of immunologic knowledge, tests of cellular immunity have promising potential for further research in this field. The historical view of the immune response to beryllium in acute and/or chronic beryllium disease is an example of the development of the interaction between mechanisms of innate and adaptive (specific), humoral and cellular immunity. The authors emphasize the increasing importance of immunological aspects in the studies of health impacts of human exposure to environmental pollutants.

Key words: beryllium-rich coal, human exposure, cellular immunity, humoral immunity

Address for correspondence: J. Petanová, Institute of Immunology and Microbiology, First Faculty of Medicine, Charles University, Studničkova 7, 12800 Praha 2, Czech Republic. E-mail: jitka.petanova@|f1.cuni.cz

https://doi.org/10.21101/cejph.a5851

\section{INTRODUCTION}

Air pollution caused by fly ash and sulphur oxides released from coal burning (1) is complicated in some places by the presence of excessive quantities of toxic elements in the emissions of power plants $(2,3)$. The studies of consequences of environmental pollution in industrial areas are paying growing attention to substances having delayed effects. Beryllium is one of the substances posing a high risk, especially when inhaled in the form of oxide. Beryllium is a lightweight metal, it is present in different minerals and also in coal. Beryllium can be extracted from bertrandite and beryl and it can be commercially used in a range of industries. Its compounds possess special chemical, physical and mechanical properties. Beryllium metal has no relevant acute oral toxicity, it is not a skin sensitizer and it has low local irritation properties, the evidence for its carcinogenicity in animal studies is weak (4). The human exposure to beryllium and soluble beryllium compounds can occur during the commercial extraction and use (5), there is a weak information about its presence in house-dust (6). Some exposed individuals develop acute or chronic reaction to beryllium, based on their genetic disposition and the immune system functions.

Occupational diseases were induced even during slight and brief contact $(7,8)$. Among healthy workers engaged in beryllium workshops, disturbances have been found in individual indicators of humoral immunity, i.e. elevated concentrations of $\operatorname{IgG}$ and $\operatorname{Ig} A$ (9), weakening of some barrier functions and increased autoimmune reactions. The occurrence of "nonoccupational" berylliosis points to the danger to the population living near plants which pollute the atmosphere with beryllium. Different concentrations of beryllium, usually not exceeding maximal acceptable concentration (MAC) values, have been determined in the atmosphere of many large towns. The elevated levels of beryllium were related to the higher beryllium content in coal which was burned there. Some types of coal in the Czech Republic contained a higher amount of beryllium which gets into cinder and fly ash (10). The use of such coal in power plants released emissions with relatively high amounts of beryllium compounds into the atmosphere (11). The concentrations of beryllium ranged in the working atmosphere between $30-800 \times 10^{-5} \mathrm{mg}$ per cubic meter, in the non-working area $0.39-1.68 \times 10^{-5} \mathrm{mg}$ per cubic meter. MAC value for the open air is $0.1 \times 10^{-5} \mathrm{mg}$ per cubic meter.

The immune system reacts with different substances from the environment. The mechanisms of innate and adaptive immunity play an important role not only in the defence against microbial stimuli. The humoral and cellular factors are necessary for sustaining physiological homeostasis, immunosurveillance and autotolerance of self-antigens. The immune system has to discriminate between harmful and harmless signals (antigens and epitopes, haptens) and it has to start the immune reaction to ensure the 
minimal damage of normal body functions after some negative impact. The immune functions are based on an interaction between different mechanisms of humoral (immunoglobulins, cytokines, the complement system, chemokines) and cellular immunity (T and B lymphocytes, macrophages, dendritic cells, natural killer cells). Different extrinsic factors (drugs, chemicals, microbes) can affect cell viability and functions, they can change the structure of autoantigens, induce an immunopathologic reaction (12). They can initiate the induction of an autoimmune reaction or disease (13). Xenobiotics can have an influence upon innate and adaptive immune system components also through non-epitope dependent mechanisms. The interaction of beryllium with the human immune system leads to hypersensitivity reactions with different clinical symptoms: allergic immune response (beryllium sensitization), acute beryllium disease (ABD), and chronic beryllium disease (CBD) (14). Acute disease is based on allergic or irritative reactions, but in some cases it can continue to the development of chronic immune-mediated granulomatous reaction $(15,16)$.

\section{Historical View: Beryllium and Humoral Immunity}

The burning of beryllium-containing coal does not liberate only beryllium compounds. The plants were subjected to a higher pollution with coal dust than the town atmosphere. Unfortunately, no control sample of persons exposed to combustion products of coal containing a small amount of beryllium was studied, unlike in the previous arsenic exposure-related study (17). According to other authors $(18,19)$, elevated levels of some humoral immune factors (immunoglobulins $\operatorname{IgG}$ and $\operatorname{IgA}$ ) at an increased activity of the pathological process were characteristic for berylliosis. Similar, though less marked, changes were found in persons who were occupationally in contact with beryllium. This indicated that the effect of beryllium compounds arising from burning of beryllium-containing coal had a more prominent effect on the increasing immunogenesis than the impact of the coal dust proper. This could be due to the potentiating qualities of beryllium in this respect (20).

With the objective of evaluating the effect of relatively low beryllium concentrations within the range of MAC values or not more than one order above, our previous study covered several aspects of the humoral immunity system in workers in two power plants $A_{1}$ and $A_{2}$ using coal with a high beryllium content, and in the population of a town near one of the above mentioned plants, located in a zone of frequent inversion situations (11). The examined sample comprised 45 workers from the plants, not living in town near power plant $A_{2}$, and 36 inhabitants of the town. The control sample included 100 healthy subjects who had no contact with beryllium and other industrial toxic agents (workers hired for work, sportsmen, and blood donors). The increased concentration of immunoglobulins IgG, IgA and IgM in the two exposed cohorts was accompanied by higher values of various autoantibodies. The level of these autoantibodies was higher in the population living in the polluted area for a long time than in the plant workers. This difference applied particularly to the lungs and was apparently due to the fact that in the given case they served as shock organs in which the products of the polluted atmosphere were mainly deposited. The elevated level of anti-pulmonary autoantibodies could be regarded as a defensive process aimed at binding and eliminating xenobiotics from the organism. Besides this, the population, compared to the workers, showed a substantially higher level of autoantibodies against thyroid gland and suprarenals. It was interesting that higher values of antibodies against the suprarenals were found in workers of power plant $A_{2}$, which is highly polluted, than in workers of power plant $A_{1}$ and the town population. The analysis of values according to sex was interesting: the levels of $\operatorname{IgG}$ and $\operatorname{IgA}$ in plant workers increased exclusively in men. At the same time, the concentration of $\operatorname{Ig} \mathrm{A}$ in male workers in plant $A_{2}$ exceeded, though not significantly, the values in men from plant $A_{1}$. No increase in the t-value of the Student's test was recorded in women except for the concentration of immunoglobulin IgM. In the nonoccupationally exposed population sample, a considerable increase in the concentration of IgG was found in men and women. The concentration of IgM, though somewhat higher in women than in men, did not exceed the values of the control cohort.

The levels of autoantibodies in the investigated groups were compared also with the levels of corresponding autoantibodies in the control cohort. The results showed an elevated level of all anti-organ autoantibodies in the power plant workers and especially in the population of the town. Autoimmune reactions in the population, as compared with the plant workers, were substantially increased in the lungs, liver, thyroid gland, and suprarenals. The values of autoimmune and antihapten reactions did not differ in the male and female population. Circulating antinuclear and antimitochondrial antibodies were detected both in plant workers and in the population; in both cases the reaction in women was higher than in men.

In this case we might have to deal with an example of regenerative coupling: autoantibodies to thyroid gland and adrenal glands take part in the regulation of hormonal activity that, in its turn, participates in regulating antibodies production. Because the strong influence of dust on inhabitants provoked a higher level of autoantibody genesis, maintenance of the necessary immunohomeostasis required higher titers of antibodies to thyroid gland and adrenal glands for amplification of the effect of hormonal regulation of the immunogenesis. The level of autoantibodies did not differ in males and females compared with the pertinent values of the control cohorts of men and women. Since the increase in the concentration of immunoglobulins differed only slightly in workers and the population, in contrast to autoantibodies, it was presumably not related to the rise in the autoantibody level but was primarily of an unspecific character. Consequently, an intensification of the immunoreactivity took place, fraught with the possibility of failure in the weakest part of immunohomeostasis regulation in the case of a new action. The specificities of such changes deserved a more detailed study.

In view of the fact that the healthy subjects revealed clinically no pathological symptoms it appeared that humoral reactions to nuclear lung fractions increased in experimental berylliosis in rat in connection with the occurrence of a determinant containing beryllium. In this case, a reaction to normal nuclei should be regarded as a reaction to the carrier of a complex antigen containing beryllium. Thus, if anti-organ autoantibodies could be an unspecific reaction to the effect of the combustion products of beryllium-containing coal, nuclear antibodies to nuclear beryllium containing fractions can be a specific marker of the effect of beryllium on the nuclear structure of lung cells. There was also experimental evidence that the effect of the coal dust itself 
produced a progressive decline in the animal's ability to form antibodies (21). For this reason it could be assumed that in our previous study (11) the increased level of anti-organ antibodies was induced not by the effect of the coal itself but by the beryllium contained in it. The difference in immunoreactivity to the effect of the same toxic agent in men and women was also interesting. A higher level of immunoglobulin IgM and antinuclear antibodies was found in healthy women exposed to combustion products of beryllium-containing coal. Reactions related to the destruction of tissue and specific anti-beryllium reactions were apparently more marked in women. Binding to sex is conspicuous in many autoimmune diseases for example systemic lupus, lupoid hepatitis, rheumatoid arthritis, myasthenia, and Hashimoto's disease. Women are almost regularly more frequently affected than men. The changes in humoral immunoreactivity cannot be regarded unequivocally as a sign of health damage in exposed persons (22).

\section{Present Day Approach: Beryllium and Cellular Im- munity}

Beryllium also gives a positive reaction in cellular immunity. Its interactions with macrophages (mainly alveolar) was known together with the knowledge of beryllium sensitization. The newer immunological studies could explain better these mechanisms and show the importance of cellular immunity instead of humoral immune factors in beryllium associated diseases. It was also found that cellular immunity is responsible for clinical manifestations of chronic beryllium disease. It is characterized by accumulation of beryllium specific CD4 ${ }^{+} \mathrm{T}$ lymphocytes in lungs (23-25) and high secretion of Th1 specific proinflammatory cytokines $(24,26)$. Rodriguez et al. (27) found that beryllium exposure specifically induced cell adhesion molecule I-CAM1 expression on the cell surface of small airway epithelial cells and release of soluble I-CAM1 into the extracellular medium. This change can help and activate a Be-specific immune response in beryllium hypersensitivity disease. These findings explain previous results of an inhibited migration of macrophages that was found in exposed persons suffering from berylliosis in vitro in old experiments $(28,29)$. New advances in research explain the interaction between beryllium and innate immune cells by activation of pathogen recognition receptors, activation of inflammasome and increased migration of dendritic cells $(30,31)$. Beryllium also stimulates the formation of reactive oxygen substances (ROS) and plays a role in Be-induced macrophage apoptosis (32). This demonstrates much better the intensity of the pathological process, that is, the degree of health damage of exposed persons. The presented results, however, confirm the long-time experience that the present limits of $2 \mu \mathrm{g}$ of Be per $\mathrm{m}^{3}$ in occupational and $0.1 \mu \mathrm{g}$ in environmental settings are not totally safe at all and are subject to discussion for quite a long time (33). As berylliosis developed in only part of the persons either occupationally or environmentally exposed to beryllium (34), genetic aspects play undoubtedly an important role $(23-25,35)$. The susceptibility for the development of beryllium sensitization is associated with HLA-DP B1 with glutamic acid at amino acid position 69 (36). Tests of cellular immunity (beryllium blood lymphocyte proliferation test - BeLPT) $(23,37)$ are based on beryllium-induced lymphocyte proliferation in vitro in sensitized workers. BeLPT is used as a marker of beryllium sensitization. Some findings
$(26,38,39)$ provide new hypothesis to explain beryllium influence upon the immune system, sustained chronic inflammation and granuloma formation in chronic beryllium disease: deficient and dysfunctional regulatory $\mathrm{T}$ lymphocytes (Treg) in the lung of patients with CBD contribute to this persistent inflammation, polymorphisms of chemokine receptor CCR5 is associated with worsening of pulmonary functions and/or macrophages engulf beryllium particles and subsequently undergo apoptosis during granuloma formation. Newer findings show that the immune response to beryllium in acute and/or chronic beryllium disease is an example of the interaction between mechanisms of innate and adaptive (specific) immunity, based on the activation of cells and changes of their functions (40) similar to autoimmune diseases. The newest research gives the supposition of possible protective role of B lymphocytes in chronic beryllium disease (41).

\section{CONCLUSION}

The knowledge of the interactions between beryllium and the immune system was changed during the years. The objective of the research in past decades was to study the possibility to use humoral immunity indicators to assess manifestations of exposure in people exposed to relatively low concentrations of beryllium in occupational and environmental settings in the context of current discussion concerning still not fully reliable MAC/TLV (threshold limit values) values for this metal. Nowadays the research interest is shifted from humoral immunity to the tests of cellular immunity and genetic studies which have promising potential for further research in this field. Research of the human exposure to beryllium needs to include the development of biologic markers of metal-induced immunologic diseases, detailed characterization of human exposure, examination of gene alleles that may confer risk, and association of exposure data with those on genetic susceptibility. It is essential that all persons with beryllium allergy will be prophylactically excluded from work at risk of exposure to beryllium.

\section{Acknowledgements}

The work was supported by grant of the Ministry of Education, Youth and Sports of the Czech Republic Q25/1.LF and by grant of GACR 17-00859S.

\section{Conflict of Interests}

None declared

\section{REFERENCES}

1. Wilson R, Colome SD, Spengler JD, Wilson DG. Health effects of fossil fuel burning. Cambridge: Ballinger; 1980.

2. Jiřele V, Nechyba L, Pachner P. A contribution to the elucidation of beryllium hygienic importance in some sorts of Sokolov Basin coals. Ceskoslov Hyg. 1966;11:329-39. (In Czech.)

3. Bezačinský $\mathrm{M}$, Pilátová $\mathrm{B}$, Jiřele $\mathrm{V}$, Bencko $\mathrm{V}$. To the problem of trace elements and hydrocarbon emissions from combustion of coal. J Hyg Epidemiol Microbiol Immunol. 1984;28(2):129-38.

4. Strupp C. Beryllium metal I. Experimental results on acute oral toxicity, local skin and eye effects, and genotoxicity. Ann Occup Hyg. 2011;55(1):30-42. 
5. Duling MG, Stefaniak AB, Lawrence RB, Chipera SJ, Virji MA. Release of beryllium from mineral ores in artificial lung and skin surface fluids. Environ Geochem Health. 2012;34(3):313-22.

6. Ibanez Y, Le Bot B, Glorennec P. House-dust metal content and bioaccessibility: a review. Eur J Mineral. 2010;22(5):629-37.

7. Eisenbud M, Wanta RC, Dustan C, Steadman LT, Harris WB, Wolf BS Nonoccupational berylliosis. J Ind Hyg Toxicol. 1949;31(5):282-94.

8. Hardy HL. The disability found in persons exposed to certain beryllium compounds. AMA Arch Ind Health. 1955;12(2):174-81.

9. Chesnokov VA, Belova AA. Chronic exposure to low concentrations of beryllium on the level of human serum immunoglobulins. Gig Tr Prof Zabol. 1979;(8):38-40. (In Russian.)

10. Bouška V, Pešek J. Quality parameters of lignite of the North Bohemian Basin in the Czech Republic in comparison with the world average lignite. Int J Coal Geol. 1999;40(2-3):211-35.

11. Bencko V, Vasilieva EV, Symon K. Immunological aspects of exposure to emissions from burning coal of high beryllium content. Environ Res. 1980;22(2):439-49.

12. Chauhan RS, Cohen Tervaert JW, Conrad K, Cooper GS, De Souza Querioz ML, Germolec DR, et al. Principles and methods for assessing autoimmunity associated with exposure to chemicals. Environmental Health Criteria 236. Geneva: WHO; 2006.

13. Pollard KM, Hultman P, Kono DH. Toxicology of autoimmune diseases. Chem Res Toxicol. 2010;23(3):455-66.

14. McCleskey TM, Buchner V, Field RW, Scott BL. Recent advances in understanding the biomolecular basis of chronic beryllium disease: a review. Rev Environ Health. 2009;24(2):75-115.

15. Cummings KJ, Stefaniak AB, Virji MA, Kreiss K. A reconsideration of acute beryllium disease. Environ Health Perspect. 2009;117(8):1250-6.

16. Santo Tomas LH. Beryllium hypersensitivity and chronic beryllium lung disease. Curr Opin Pulm Med. 2009;15(2):165-9.

17. Bencko V, Wagner V, Wagnerová M, Bátora J. Immunological profiles in workers of a power plant burning coal rich in arsenic content. J Hyg Epidemiol Microbiol Immunol. 1988;32(2):137-46.

18. Resnick H, Roche M, Morgan WKC. Immunoglobulin concentrations in berylliosis. Am Rev Respir Dis. 1970;101(4):504-10.

19. Vasilieva EV, Nikitina LS, Orlova AA. Concentrations of immunoglobulins in berylliosis. J Hyg Epidemiol Microbiol Immunol. 1977;21(3):25460 .

20. Salvaggio JE, Flax MH, Leskowitz S. Studies in immunisation: III. The use of beryllium as a granuloma-producing agent in Freund's adjuvant J Immunol. 1965;95(5):846-54.

21. Zarkower A. Alterations in antibody response induced by chronic inhalation of SO2 and carbon. Arch Environ Health. 1972;25(1):45-50.

22. Wagner V, Wagnerová M. Ecoimmunology. Prague: Avicenum; 1988. (In Czech.)

23. Amicosante M, Fontenot AP. T cell recognition in chronic beryllium disease. Clin Immunol. 2006;121(2):134-43.

24. Samuel G, Maier LA. Immunology of chronic beryllium disease. Curr Opin Allergy Clin Immunol. 2008;8(2):126-34.

25. Falta MT, Bowerman NA, Dai S, Kappler JW, Fontenot AP. Linking genetic susceptibility and $\mathrm{T}$ cell activation in beryllium-induced disease. Proc Am Thorac Soc. 2010;7(2):126-9.
26. Sawyer RT, Maier LA. Chronic beryllium disease: an updated model interaction between innate and acquired immunity. Biometals. 2011;24(1):117.

27. Rodriguez S, Kunde YA, McCleskey TM, Hong-Geller E. Upregulation of I-CAM1 in response to beryllium exposure in small airway epithelial cells. Toxicol Lett. 2008;179(3):140-7.

28. Henderson WR, Fukuyama K, Epstein WL, Spetler LE. In vitro demonstration of delayed hypersensitivity in patients with berylliosis. J Invest Dermatol. 1972;58(1):5-8.

29. Price CD, Pugh A, Pioli EM, Williams WJ. Beryllium macrophage migration inhibition test. Ann N Y Acad Sci. 1976;278:204-11.

30. McKee AS, Fontenot AP. Interplay of innate and adaptive immunity in metal-induced hypersensitivity. Curr Opin Immunol. 2016;42:25-30.

31. Wade MF, Collins MK, Richards D, Mack DG, Martin AK, Dinarello CA, et al. TLR9 and IL-1R1 promote mobilization of pulmonary dendritic cells during beryllium sensitization. J Immunol. 2018;201(8):2232-43.

32. Rana SV. Metals and apoptosis: recent developments. J Trace Elem Med Biol. 2008;22(4):262-84

33. Fields S. Toxic beryllium: New solutions for a chronic problem. Environ Health Perspect. 2001;109(2):A74-9.

34. Donovan EP, Kolanz ME, Galbraith DA, Chapman PS, Paustenbach DJ. Performance of the beryllium blood lymphocyte proliferation test based on a long-term occupational surveillance program. Int Arch Occup Environ Health. 2007;81(2):165-78.

35. Kelleher P, Pacheco K, Newman LS. Inorganic dust pneumonias: the metal-related parenchymal disorders. Environ Health Perspect. 2000;108(Suppl 4):685-96

36. Fontenot AP, Maier LA. Genetic susceptibility and immune-mediated destruction in beryllium-induced disease. Trends Immunol. 2005;26(10):543-9.

37. Stange AW, Furman FJ, Hilmas DE. The beryllium lymphocyte proliferation test: relevant issues in beryllium health surveillance. Am J Ind Med. 2004;46(5):453-62.

38. Mack DG, Lanham AM, Falta MT, Palmer BE, Maier LA, Fontenot AP. Deficient and dysfunctional regulatory $T$ cells in the lungs of chronic beryllium disease subjects. Am J Respir Crit Care Med. 2010;181(11):12419.

39. Sato H, Silveira L, Spagnolo P, Gillespie M, Gottschall EB, Welsh KI, et al. CC chemokine receptor 5 gene polymorphisms in beryllium disease. Eur Respir J. 2010;36(2):331-8.

40. Fontenot AP. Immunologic effects of beryllium exposure. Ann Am Thorac Soc. 2018;15(Suppl 2):S81-5.

41. Greaves SA, Atif SM, Fontenot AP. Adaptive immunity in pulmonary sarcoidosis and chronic beryllium disease. Front Immunol. 2020;11:474. doi: 10.3389 /fimmu.2020.00474.

Received June 11, 2019 Accepted in revised form July 14, 2020 